\title{
Significance of quality in the tourism industry: Research study on the perception of stakeholders in tourism
}

\author{
Dalibor Redžić ${ }^{*}$ \\ ${ }^{1}$ Singidunum University, Belgrade
}

\begin{abstract}
Quality in the tourism and hospitality industry presupposes the consistent delivery of products and guest services being in line with expected standards. One of the key challenges that managers in the hospitality industry face today is to provide quality services which are one of the basic conditions for realization of business goals in the global tourism market. Today, there are various tools and mechanisms which greatly facilitate the identification of quality in the tourism and hospitality industry. In order to increase the quality to a higher level, managers should identify, monitor, and weigh the impacts of costs and its activities directed towards the continuous improvement of the quality of all business operations of the company. The present study shows that hotel guests prefer quality service experience as delivered value for their money, comfortable accommodation with beautiful views, communicative and friendly staff, as well as varied and delicious foods. Moreover, the survey shows that there are numerous opportunities for further improvements in the quality of the services in the hospitality industry. Other results of the survey indicate that the key elements for successful performance of hotel companies in the future are guest satisfaction, their loyalty and word of mouth advertising. The outcomes of the survey suggest that hotel companies, in order to build excellence and profitability, should particularly focus on the quality of services, retention of existing and attracting new guests, continuous control and quality improvement, selection, training and motivation of their employees, search for best practices through benchmarking and quality accreditation through ISO or EFQM schemes.
\end{abstract}

Keywords: quality, hotel guests, services, hotel managers, tourism and hospitality JEL clasification: L15, L84, L83

\section{Značaj kvaliteta u turističkoj industriji: Istraživačka studija o percepciji stejkholdera u turizmu}

Sažetak: Kvalitet u turizmu i hotelijerstvu podrazumeva doslednu isporuku proizvoda i usluga gostima u skladu sa očekivanim standardima. Jedan od ključnih izazova sa kojima se danas suočavaju menadžeri u hotelijerstvu jeste obezbeđenje kvalitetnih usluga, što je jedan od osnovnih uslova za ostvarivanje poslovnih ciljeva na globalnom turističkom tržištu. Danas, za merenje i poboljšanje kvaliteta usluga postoje razni alati i mehanizmi koji u velikoj meri olakšavaju identifikaciju kvaliteta u turizmu i hotelijerstvu. U cilju povećanja kvaliteta na viši nivo menadžeri trebaju da identifikuju, kontrolišu, odmere uticaje troškova i svoje aktivnosti usmere ka kontinuiranom unapređenju kvaliteta u svim poslovnim operacijama preduzeća. Ovaj istraživački rad ukazuje da gosti hotela doživljavaju kvalitetnu

*dalibordredzic@ hotmail.com 
Redžić, D. - Significance of quality in the tourism industry: Research study on the perception of stakeholders in tourism - Hotel and Tourism Management, 2018, Vol. 6, No. 2: 11-20.

uslugu kao isporučenu vrednost za novac, udoban smeštaj sa lepim pogledom, komunikativno i ljubazno osoblje, raznovrsnu i ukusno pripremljenu hranu. Takođe, istraživanje pokazuje da postoje brojne mogućnosti za dalje poboljšanje kvaliteta usluga u ugostiteljskoj delatnosti. Ostali rezultati istraživanja pokazuju da su ključni elementi za uspešne performanse hotelskih preduzeća u budućnosti zadovoljstvo gostiju, lojalnost gostiju i usmeno oglašavanje (od usta do usta). Ishodi istraživanja ukazuju da se hotelska preduzeća u cilju građenja izvrsnosti i profitabilnosti trebaju posebno fokusirati na kvalitet usluga, zadržavanje postojećih i privlačenje novih gostiju, kontinuiranu kontrolu i poboljšanje kvaliteta, selekciju, obuku i motivaciju zaposlenih, traženju najboljih praksi kroz benčmarking i akreditaciju kvaliteta putem ISO i EFQM šema.

Ključne reči: kvalitet, gosti hotela, usluge, hotelski menadžeri, turizam i hotelijerstvo JEL klasifikacija: L15, L84, L83

\section{Introduction}

Quality is the ability of a product to satisfy or exceed customer expectations. Accordingly, organizations must understand all the features of services that contribute to the value of users and lead to their satisfaction and loyalty (Evans \& Lindsay, 2010). Quality management is directly related to continuous quality improvement. Quality management involves work to develop specific products, uses different methods and tools, and includes repetition and evaluation (European Comission, 2000).

The International Organization for Standardization (ISO) defines quality management as "all management functions that determine objectives, quality policies and responsibilities that are implemented through planning, control, insurance and quality improvement within the quality system" (ISO, 2015). As the companies over the time began to recognize the need for a wider range of quality, a new concept of "total quality" (TQ) emerged. Total quality is a quality management system aimed at continuously increasing customer satisfaction with low real costs. TQ can be understood as a complete system approach that functions horizontally through functions and departments, includes all employees in the company and includes a supply chain and a customer service chain. Also, this systemic approach emphasizes adapting to constant change and learning, which is the key to the success of an organization (Evans, 2007).

Consequently, based on such an organization and management process, hotel companies will have to adapt to a number of changes in order to produce and offer the appropriate products that will meet the expectations of service users. Today, the implementation of the TQM system is gradually being carried out in the tourism sector in order to motivate human resources and create a competitive advantage that would improve the company's business on the market.

\section{The importance of quality in tourism and hospitality}

Quality assurance can be defined as planned and systematic set of activities that companies should be focused on, while providing the services of the appropriate quality with the confidence that they will meet the requirements of their customers.

In order to successfully ensure quality, one has to emphasize the excellence of two important points in business (Vilimova, 2014):

- Design of products,

- Quality control. 
The quality management system for hotel services is an approach focused on results. Today there are more and more users who are willing to deduct more money for a service that meets or exceeds their expectations. Accordingly, the level of service quality is a key factor in the perception of users after using the service (Hayes et al., 2012). By constantly creating value for the users, the hotel company builds its impressive image, which is an important factor in keeping existing and attracting new service users. Also, management must recognize the importance of retention of users, since it is known that attracting new users is expensive and a long-lasting process (Odindo \& Devlin, 2007).

As the tourist market is becoming more and more competitive today, the issue of quality has become crucial for the survival of hotel companies on the market. This was significantly influenced by two factors, such as the emergence of new tourists who are willing to pay and use only quality services and the adoption of new regulations regarding the respect of consumers' rights. This means that due to increased competition in the market, hotel companies became aware of the importance of quality which is a key source for increasing the competitive advantage (Lazić et al., 2013). Assessing the quality of services (most often through insight into guest reviews or online questionnaires) is an important instrument that helps hotel owners identify and solve problems.

The following quality components are used to develop and implement a quality service system in hotel companies (Go \& Govers, 2000):

\begin{tabular}{cl}
\hline 1. & Consider users who are offered the service \\
\hline 2. & Determine what users want \\
\hline 3. & Develop procedures and provide users with the service they want \\
4. & Train and empower employees \\
5. & Implement revised systems \\
\hline 6. & Evaluate and modify service delivery systems \\
\hline
\end{tabular}

By carrying out a regular and systematic analysis of the results of quality assessment, management manages a number of advantages that are reflected in (Krishnamoorthy \& Dlima, 2014):

- Measuring the appropriate level of expectations and user needs and comparing the obtained results with perceived quality,

- Identification of quality improvement activities, and

- Competitive quality control with the help of benchmarking.

Today, providing quality services is one of the main challenges for managers that will face in the coming years. This will be the key condition for the success of a hotel company in a competitive global market.

\section{Tools to measure the quality of services in hospitality}

Today, despite the constant efforts of hotel companies to provide quality services a gap may occur between the offered and the perceived (experienced) quality.

In order to avoid this, it is necessary to constantly measure the quality of services that are achieved with the help of certain models being the best known (Quality managment in hospitality, 2018):

- Perceived service quality model,

- Model of five gaps,

- SERVQUAL model,

- Model of a critical incident technique. 
Redžić, D. - Significance of quality in the tourism industry: Research study on the perception of stakeholders in tourism - Hotel and Tourism Management, 2018, Vol. 6, No. 2: 11-20.

The perceived quality service model is a useful tool for understanding the factors that influence the perception of the quality of the users after using the services of the hotel company (Angelova \& Zekiri, 2011). The anticipated quality is influenced by a number of factors based on the experience of using the services of a particular company, created by the image of a specific product, the verbal recommendation and the requirements of the service users.

Model of five gaps. It is an instrument used by managers to more precisely define quality management objectives (Shahin \& Samea, 2010). The model is oriented towards the user and the service delivery proces. When assessing the quality of services, users will be affected by five gap series. Quality management systems must aim to close the gap that exists in the service process, and therefore improve the quality so that users can fulfill their expectations after using the services.

SERVQUAL model. The model is used to measure the perceived quality of services. In this model, perceived quality is measured in two ways (Daniel, 2010):

- Internal measurement,

- External measurement.

Internal measurement refers to the measurement of objective criteria (functional quality, technical quality, process quality and total quality) that are set or developed by a particular organization. The SERVQUAL instrument measures five key characteristics: tangibility, reliability, responsiveness, security, and empathy. With the help of SERVQUAL model, organizations have the ability for limitless monitoring of the internal service quality. External measurement includes subjective expectations, desires, needs, and experiences of service users (expected quality, perceived quality and experience-based quality).

Critical Incident Technique (CRIT). This instrument mesaures what happens in different "moments of truth" based on the collected samples over time. The tool provides useful information for product development, quality improvement and the expansion of marketing domains. Organizations based on this instrument can also understand and solve customers problems in a flexible way.

Measuring quality of services and quality assurance is a long-term process with high costs for the company, but it pays over time as opposed to the quality of services. Managers need to identify, monitor and evaluate the impact of costs on service quality.

Key categories of quality costs are (Elbireer et al., 2010):

- Prevention of costs,

- Insurance (employee time and administrative costs),

- External costs.

Cost and benefit coefficient can be calculated using the cost equation that is not included in quality and quality assurance in relation to operating cost savings and user returns (COQ, $\underline{2018)}$.

\section{Mechanisms for quality recognition in tourism industry}

\subsection{Quality labels}

Today, there are numerous mechanisms for recognizing quality in the tourism industry. The main reasons for establishing quality properties of accommodation capacities through some form of classification schemes are: 
Redžić, D. - Significance of quality in the tourism industry: Research study on the perception of stakeholders in tourism - Hotel and Tourism Management, 2018, Vol. 6, No. 2: 11-20.

- Informing users, which would allow them to make choices based on the standardized quality criteria;

- Encouringing investments and improving service quality by implementing international quality standards.

The most commonly used measurement methods are (Bennett et al., 2007):

- $\quad$ Physical measures (room size),

- Quality of services.

Existing quality standards and labels include:

- Star rating system (hotels are rated from one to five stars). The diamond assessment system is carried out in the United States by the American Automobile Association (hotels and restaurants are rated from one to five diamonds);

- Tripadvisor.com, a travel website that evaluates the quality of accommodation capacities;

- International Organization for Standardization (ISO), which has published several series of standards that apply in the tourism sector;

- Eco-labels are increasingly represented in the tourism sector. First, the "green labels" are developed for hotel companies with the aim of improving environmental management. Over time, these labels began to be applied by other entities within the tourism sector (Bennett et al., 2007).

\subsection{European Foundation for Quality Management (EFQM)}

The European Quality Management Foundation was created to promote a standard approach in quality management for all organizations operating in Europe with the aim of contributing in order to ensure the sustainable practice quality.

The main characteristics of EFQM are that:

- It has the role of advisor in quality management,

- Awards the most successful companies,

- It does not have the ability to issue certificates.

Figure 1: The EFQM model

\begin{tabular}{|c|c|c|c|c|}
\hline \multirow{5}{*}{$\begin{array}{c}\text { Leadership } \\
10 \%\end{array}$} & \multirow{2}{*}{$\begin{array}{l}\text { People } \\
\text { Management 9\% }\end{array}$} & \multirow{5}{*}{$\begin{array}{c}\text { Process } \\
14 \%\end{array}$} & $\begin{array}{l}\text { People } \\
\text { Satisfaction 9\% }\end{array}$ & \multirow{5}{*}{$\begin{array}{l}\text { Operational } \\
\text { results } 15 \%\end{array}$} \\
\hline & & & & \\
\hline & \multirow{3}{*}{$\begin{array}{l}\text { Policy \& } \\
\text { Strategy } 8 \% \\
\text { Resources 9\% }\end{array}$} & & $\begin{array}{l}\text { Customer } \\
\text { Satisfaction 20\% }\end{array}$ & \\
\hline & & & & \\
\hline & & & $\begin{array}{l}\text { Impact on } \\
\text { Society } 6 \%\end{array}$ & \\
\hline Enabling F & ors $\mathbf{5 0 \%}$ & & & sults $50 \%$ \\
\hline
\end{tabular}

Source: Go \& Govers, 2000

Figure 1 is based on a set of eight fundamental concepts and is a framework for selfevaluation of the organization. 
Redžić, D. - Significance of quality in the tourism industry: Research study on the perception of stakeholders in tourism - Hotel and Tourism Management, 2018, Vol. 6, No. 2: 11-20.

Factors such as policies and strategies, leadership, employee management, processes and resources are calculated on the basis of measurability, systematic and system introduction, while results such as the community impact, user satisfaction and operational results, are being assessed on the basis of comparisons with competing companies, contemporary trends and achieved goals.

\subsection{Malcolm Baldridge National Quality Award}

The award represents the highest level of national recognition for quality in the United States. This prestigious award is awarded by the Institute of Standards, Technology and Trade (NIST). The award promotes excellence, increased awareness and understanding of quality as a key element in increasing competitive advantage. The Baldridge award covers all sectors and is awarded to the most successful company that meets strict quality criteria. The award is compatible with Six Sigma and ISO 9000 series of standards.

\section{Case study: Perception of stakeholders of the quality of hotel services}

\subsection{Research methodology}

The study aims to explore how stakeholders in tourism experience the quality of hotel services, while working on improving the hotel operations in the future. Based on the obtained results, certain strategies have been proposed in order to improve the service delivery. The study was conducted in the period from May 5th, 2018 through June 15th, 2018. Qualitative research was conducted through structured interviews, customized questionnaires and telephone surveys.

The study involved 100 people with the following backgrounds:

- Status: hotel owners (30), stakeholders in tourism (board members and presidents of associations) (15), professors (25), students (30);

- Gender: $80 \%$ men, $20 \%$ women;

- Age: 23-60 years;

- Location: 50\% Belgrade, 30\% Novi Sad; $20 \%$ Niš;

- Number of replies received via: e-mail (55), interviews (20), phones (25).

Participants in the research (members and presidents of the associations, professors, hotel owners and students) represent a key resource in the tourism sector, and their suggestions and opinions are considered important for the improvement of the tourism industry.

\subsection{Questions for research participants and answers}

1. What represents the quality of services in the hotel company?

Received answers are:

- Value for money, clean and comfortable rooms, friendly staff, healthy and tasty food (70\% of the respondents);

- Predictability and satisfaction of the needs of user services (25\% of the respondents);

- Other responses include: kindness and communication of employees, ambience, fast delivery of services (5\% of the respondents). 
2. Do you think hotels in your city provide quality services?

Answers include the following options:

- Several hotels provide top-quality services. Most hotels provide average quality services, and a small percentage of hotels provide poor quality services (85\% of the respondents);

- It depends on the category of the hotel and the price of the accommodation. There are hotels of high category with 4 and 5 stars which provide high quality services for a high price, and a small number of hotels with 1 or 2 stars offer poor quality services with low price (15\% of the respondents).

3. What should hotels do in order to improve the quality of services?

Answers are:

- Apply total quality management system (50\% of the respondents);

- Take into account the opinions and suggestions of service users $(20 \%$ of the respondents);

- Assign hotel management to a more efficient manager (15\% of the respondents);

- Employ quality staff and conduct continuous employee training (10\% of the respondents);

- Improve the exterior and interior of the hotel (5\% of the respondents).

4. How important is user satisfaction for the future business of the hotel?

Answers:

- Hotel companies can successfully operate on the market if they meet the needs of the users, constantly measure their satisfaction, analyze the results obtained and improve the quality of services (55\% of the respondents);

- Keeping existing and attracting new customers is very important for the successful operation of the hotel in the future. Based on this data, managers should do everything in their power to satisfy their customer requests $35 \%$ of the respondents);

- Satisfied users always return to the hotel and bring new users. Based on this, the hotel company will continue to operate in the future and will not face the problems of capacity building ( $10 \%$ of the respondents).

5. How can quality of service contribute to customer satisfaction?

Answers:

- For certain users, the perceived quality of services varies considerably from the expected quality, which results in their dissatisfaction (65\% of the respondents);

- The main differences between the expected service (advertising, hotel website and brochures) and the services used, lead to user dissatisfaction $(35 \%$ of the respondents).

\section{Analysis of the received results}

- For most respondents (70\%), the high quality of hotel services is an important condition for a customer that they can receive the value for their money. Also, they would prefer clean and comfortable rooms, friendly staff, healthy and delicious food. 
- $\quad 85 \%$ of the respondents believe that most hotels in Belgrade, Novi Sad and Niš offer quality services. Although this is a good indicator, there are still some hotels with a lower quality service.

- Applying a total quality management system (50\%), customer opinions and suggestions $(20 \%)$, hotel management by more efficient managers (15\%), quality staff $(10 \%)$ and interior and exterior improvements $(5 \%)$ represent the suggestions of the respondents to improve the quality of hotel services. Bearing in mind that the survey sample is made up of people connected with the tourism industry, their suggestions should be taken into account and applied by the hotelier in order to improve the hotel's business on the market.

- $55 \%$ of the respondents answered that continuous measurement of customer satisfaction, analysis and improvement of service quality is a key factor for successful hotel operations in the future. Also, retaining existing ones and attracting new customers are the other elements that hotel managers should be aware of.

- In the end, respondents believe there should be no gap between the perceived and expected quality of services, otherwise the guests would be dissatisfied. Therefore, hotel companies should not advertise or represent their attributes in an unrealistic way.

The obtained research results are in line with the theoretical concepts of the tourism industry related to the quality of services, and confirm that quality plays a key role in attracting and retaining hotel customers. Future research on the expectations, needs and wishes of the customers is needed in order to propose appropriate mechanisms leading to excellence in the provision of quality services in the tourist and hotel sector.

\section{Conclusion}

Quality and high level services are concepts that are indissolubly associated with the tourism and hospitality industry. Quality assurance implies long-term commitment and incurs costs for a hotel company, but over time it leads to more profit in relation to companies that ignore it.

Today, there are various mechanisms that contribute to ensuring the quality of tourist services. The main reasons for establishing quality marks through classification schemes are the information of service users (based on which they could measure and compare the quality of services and stimulate investment and improve quality through the implementation of international standards). The research has shown that samples directly related to tourism (professors, members and presidents of associations, hotel owners and students) experience the quality of hotel services as value for their money, comfortable accommodation, friendly staff and delicious food. Also, the research has shown that most hotels in Belgrade, Novi Sad and Niš provide quality services. This indicates that there is always a possibility for further improvement and excellence of hotel services. Based on other results we can conclude that the most important factors for a successful hotel operation in the future are customer satisfaction, customer retention and word of mouth advertising.

From a managerial point of view, this paper is significant because it helps managers to identify, record and weigh with more accuracy the impacts of quality cost-profit and be in a position to prioritise quality improvement processes. Also, managers can determine the costquality ratio using the cost equation that does not relate to the quality and cost of quality assurance in relation to the benefits of saving operating costs and the rate of return of customers. 
From a theoretical point of view, the findings of this study indicate that the quality of services plays a key role in the satisfaction of hotel custumers. Also, research indicates that the quality of hotel services as a key source of competitive advantage provides a basis for attracting and retaining customers.

The paper suggests that hotel companies should not advertise amenities that they do not have on their own property in order to present it as desirable, although such methods can attract guests initially. Once these features are verified on the spot and their customers' expectations are not met, the hotel customers will become very disappointed, which will lead to the bad reputation of the hotel. Also, the paper recommends that hotel companies should focus on the quality of services and customer satisfaction, continuous improvement of quality, retention of existing customers and meeting and exceeding their expectations, employment of quality staff, regular training and strengthening of service orientation employees, searching for best practices through benchmarking, and a constant quest for quality accreditation through different schemes such as ISO and EFQM standards or eco-labels.

\section{Study limitations and future research}

In the conducted research there are several methodological limitations that could influence the results obtained, as well as the conclusions that are made on the basis of those results. The survey used a questionnaire as a data collection form, and filling it in a manner that assures quality required a longer time. As a limitation of the conducted research, it can be said that a part of the respondents who filled in the questionnaire did not cover all the questions, especially those questions whose answering required more time. In addition to a small number of the focused sample, most of them are 23 to 35 years old (50\% of respondents), so it can be assumed that these are younger people in the years when they show a high interest in the fun aspects of the hotel offer, and not so much in the aspects of the quality of hotel services. The attitudes to the quality of services are influenced by the lifestyle and years, experience and knowledge of the respondents in the research, and according to the results of the research, it can be concluded that most respondents share the same values. Also, when research was conducted some of the respondents could not, did not want, were not interested or did not have the time to fill in the questionnaire because they were on vacations or business trips.

Future research might consider how tourism stakeholders perceive service quality and its effect on their satisfaction and behaviours. Another avenue for future research can be using additional variables such as perceived value and customer loyalty which can determine the unexplained variance in price acceptance. Besides, future research may also include emotions of tourism stakeholders in the existing framework.

\section{References}

1. Angelova, B., \& Zekiri, J. (2011). Measuring Customer Satisfaction with Service Quality Using American Customer Satisfaction Model (ACSI model). International Journal of Academic Research in Business and Social Sciences, 1(3), 232-258. https://doi.org/10.6007/ijarbss.v1i2.35

2. Bennett, O., Greeve, M., \& Cancel, C. (2007). Standardisation and Quality Labels for EU Tourist Services. Retreived June 2, 2018 from http://www.europarl.europa.eu/RegData/etudes/etudes/join/2007/379230/IPOLTRAN_ET(2007)379230_EN.pdf

3. Cazell, B., \& Ulmer, J. (2009). Measuring Excellence: A Closer Look at Malcom Baldridge National Quality Award Winners in the Manufacturing Category. 
Redžić, D. - Significance of quality in the tourism industry: Research study on the perception of stakeholders in tourism - Hotel and Tourism Management, 2018, Vol. 6, No. 2: 11-20.

Managment \& Inovation, 4(1) 134-142. http://dx.doi.org/10.4067/S0718$\underline{27242009000100012}$

4. COQ-Cost of quality (2018). Cost of quality and organizational objectives. Retreived May 19, 2018 from http://asq.org/learn-about-quality/cost-ofquality/overview/overview.html

5. Daniel, C., \& Beringung, L. (2010). Using the SERVQUAL Model to Assess Service Quality and Customer Satisfaction: An Empirical Study of Grocery Stores in Umea (Master thesis). Umea University, Umea, Sweden.

6. Elbireer, A., Gable, A., \& Jackson, B. (2010). Cost of Quality at a Clinical Laboratory in a Resource Limited Country. Makerere Journal of Higher Education, 41(7), 429433. https://doi.org/10.1309/LMCZ0ZFR80QWIBEM

7. European Comission, Towards Quality Coastal Tourism (2000). Integrated Quality Managment (TQM) of Coastal Tourist Destinations. Retreived June 5, 2018 from file:///C:/coastal en 510\%20(1).pdf

8. Evans, J. (2007). Quality and Performance Excellence: Managment, Organization and Strategy. Boston: Cengage Learning.

9. Evans, J., \& Lindsay, W. (2010). Managing for Quality and Performance Excellence. Boston: Cengage Learning.

10. Go, F., \& Govers, R. (2000). Integrated quality management for tourist destinations: A European perspective on achieving competitiveness. Tourism Management, 21(1), 79-88. https://doi.org/10.1016/S0261-5177(99)00098-9

11. Hayes, D., Ninemeier, J., \& Miller, A. (2012). Foundations of Lodging Managment. 2nd editoin, London: Pearson Education.

12. International Organization for Standardization (ISO). (2015). Quality managment $\begin{array}{lllll}\text { principles. } & \text { Retreived } & \text { May } & 12, & 2018 \\ \end{array}$ https://www.iso.org/files/live/sites/isoorg/files/archive/pdf/en/pub100080.pdf

13. Krishnamoorthy, B., \& Dlima, C. (2014). Benchmarking as a measure of competitiveness. International Journal of Process Management and Benchmarking, 4(3), 342-359. https://doi.org/10.1504/IJPMB.2014.063240

14. Lazić, J., Cvijanović, J., Ljumović, I. (2013). Međunarodni standardi upravljanja kvalitetom u turizmu [International standards for quality management in tourism]. Menadžment u hotelijerstvu i turizmu, 1(2), 36-46

15. Odindo, C., \& Devlin, J. (2007). Customer Satisfaction, Loyality and Retention in Financial Services, Financial Services. Retrieved May 22, 2018 from https://www.nottingham.ac.uk/business/businesscentres/crbfs/documents/researchrepo rts/paper48.pdf

16. Quality managment in hospitality (2018). Hospitality industry. Retreived May 15, 2018 from http://qualitymanagementinhospitality.zohosites.com/frameworks-andmethodologies.html

17. Shahin, A., \& Samea, M. (2010). Developing the Models of Service Quality Gaps: A Critical Discussion. Business Managment and Strategy, 1(1), 1-11. https://doi.org/10.5296/bms.v1i1.395

18. Vilimova, A. (2014). Analysys of the Customer Satisfaction in the Restaurant Planet Sushi (bachelor thesis). Institute of Hospitality Managment, Prague, Czech Republic.

Received: 10 August 2018; Sent for revision: 9 November 2018; Accepted: 27 November 2018 